\title{
PENGUATAN SISTEM PRESIDENSIAL DI INDONESIA: \\ ANALISIS TERHADAP UNDANG UNDANG NO 7 TAHUN 2017 TENTANG PEMILIHAN UMUM
}

\section{Muhammad Ibrahim Rantau}

Email:ibrahimrantau2013@gmail.com

\begin{abstract}
Abstrak
Sistem presidensialisme yang disertai dengan keadaan multipartai ekstrem di Indonesia ternyata telah menghasilkan pemerintahan minoritas dan terbelah, yang mengharuskan presiden terpilih untuk melakukan kompromi politik di parlemen demi mendukung efektifitas jalannya pemerintahan. Penelitian ini mencoba menganalisis perubahan dalam revisi Undang Undang No 7 tahun 2017 tentang Pemilu yang dianggap memiliki pengaruh dalam penguatan sistem presidensial di Indonesia. Beberapa pasal krusial yang dianggap berpengaruh terhadap upaya penguatan sistem presidensial adalah tentang ambang batas presiden dan parlemen, serta keserentakan pemilihan presiden dan parlemen.
\end{abstract}

Kata kunci: Presidensialisme, pemerintahan minoritas, ambang batas presiden, ambang batas parlemen. 


\section{A. PENDAHULUAN}

Konstitusi telah mengatur bahwa sistem kekuasaan pemerintahan yang menjadi pilihan bangsa Indonesia adalah sistem presidensial, sebagaimana tergambar dalam batang tubuh Undang Undang Dasar 1945 pasal 4 hingga pasal 16. Pilihan untuk menjadikan presidensialisme secara murni sebagai sistem kekuasaan pemerintah semakin tampak dalam pasal 6, dimana Presiden dan Wakil Presiden dipilih dalam satu pasangan secara langsung oleh rakyat. Selain itu Presiden memegang penuh kekuasaan eksekutif dengan dibantu oleh para Menteri yang diangkat dan diberhentikan oleh Presiden. Penegasan tentang sistem presidensialisme juga terlihat dalam fungsi check and balances antara Presiden dan Parlemen dimana Presiden tidak bisa diberhentikan dengan begitu saja oleh parlemen, kecuali setelah melewati proses peradilan yang panjang. Begitu juga sebaliknya, dalam pasal 7c disebutkan bahwa Presiden tidak dapat membekukan dan membubarkan parlemen. ${ }^{1}$

Namun begitu, sistem presidensialisme di Indonesia juga bukan tanpa polemik. Kekuasaan presiden sebagai penyelenggara pemerintahan kerap kali tersandera oleh suasana politik di parlemen. Bahkan dalam beberapa hal yang menjadi kewenangan prerogatif Presiden, seperti pembentukan kabinet, penunjukan pejabat-pejabat tinggi negara, hingga penentuan pimpinan angkatan bersenjata, Presiden kerap harus lebih mempertimbangkan komposisi dan stabilitas kekuatan politik pendukung pemerintah di parlemen daripada menerapkan merit sistem. Dukungan dan stabilitas politik di parlemen sangat dibutuhkan oleh Presiden demi kelancaran dan efektifitas jalannya pemerintahan. Suatu kondisi yang lebih mirip dengan sistem parlementer daripada presidensiil.

Salah satu penyebab yang menjadikan sistem check and balances antara Pemerintah dan DPR belum efektif dalam mendukung jalannya pemerintahan adalah bahwa sistem presidensial kita ditengarai tidak kompatibel dengan kondisi multipartai yang menjadi kecenderungan politik di Indonesia pasca reformasi. ${ }^{2}$ Kekuasaan DPR yang cukup kuat dalam menjalankan fungsi kontrol terhadap pemerintah, ditambah dengan komposisi DPR yang multi partai, membuat Presiden sangat sulit mengkondisikan dukungan di parlemen. Akhirnya, untuk mendapatkan

\footnotetext{
${ }^{1}$ Batang tubuh Undang Undang Dasar 1945, Bab III, Pasal 4-16, tentang Kekuasaan Pemerintahan Negara, dalam Undang Undang Dasar 1945 dan Amandemennya, (Jakarta, BIP: 2017)

${ }^{2}$ Hanta Yudha, Presidensialisme Setengah hati: Dari Dilema ke Kompromi, (Jakarta, Gramedia Pustaka Utama:1998) hal 1-8,
} 
dukungan dari parlemen, presiden harus membentuk koalisi pendukung pemerintah dengan basis politik transaksional. Hal ini membuat pemerintahan menjadi tidak stabil, karena dukungan dari parlemen setiap saat bisa berubah sesuai dengan dinamika dan perkembangan politik.

Upaya untuk memperkuat sistem pemerintahan yang stabil dan fungsi parlemen yang efektif inilah yang menjadi salah satu semangat dilakukannya revisi terhadap undang undang Pemilihan Umum. Undang undang No 7 tahun 2017 tentang Pemilihan Umum merupakan produk undang undang yang dihasilkan dari adanya tuntutan konstitusional bahwa pada pemilu tahun 2019, pemilihan Presiden dan Wakil Presiden, serta Pemilihan anggota DPR, DPRD dan DPD harus dilaksanakan secara serentak. ${ }^{3}$ Keserentakan Pemilihan Presiden serta Wakil Presiden dan Pemilihan anggota DPR, DPRD dan DPD berangkat dari adanya Putusan Mahkamah Konstitusi No. 14/PUU-XI/2013, yang mengamanatkan bahwa Pemilihan Presiden dan Pemilihan anggota Legislatif harus dilaksanakan secara bersamaan.

Dalam penjelasan terhadap putusannnya, Mahkamah Konstitusi beralasan bahwa pelaksanaan pemilu secara serentak selain demi efisiensi anggaran, juga untuk mengurangi potensi negosiasi politik antara presiden dan partai politik dalam rangka mendapatkan dukungan di parlemen. Negosiasi politik kerapkali lebih bersifat transaksional dan dikhawatirkan akan mempengaruhi dan mereduksi kekuasaan presiden dalam menjalankan pemerintahan. ${ }^{4}$ Dengan pelaksanaan pemilu secara serentak, dukungan koalisi di parlemen terhadap presiden diharapkan akan lebih berdasarkan kepada kesamaan visi dan misi, yang permanen bahkan

\footnotetext{
${ }^{3}$ Undang undang Nomor 7 tahun 2017 merupakan unifikasi dari tiga undang-undang yang menjadi komponen hukum penyelenggaraan pemilu, yaitu Undang undang Nomor 42 tahun 2008 tentang Pemilihan Presiden dan Wakil Presiden, Undang Undang Nomor 15 Tahun 2011 tentang Penyelenggaraan Pemilihan Umum, dan Undang Undang Nomor 8 tahun 2012 Tentang Pemilihan Anggota DPR, DPD, dan DPRD. Penyatuan ketiga undang undang tersebut dianggap sangat krusial mengingat sejumlah aspek penting bagi penyelenggaraan pemilu yang diatur dalam 3 undang undang tersebut tidak memiliki standar yang sama. Selain itu beberapa aspek penting juga mangandung kontradiksi antara satu undang undang dengan yang lainnya, sehingga menimbulkan potensi ketidak pastian hukum bagi penyelengaraan pemilihan Presiden dan Legislatif serentak pada tahun 2019.

4 Putusan Mahkamah Konstitusi No.14/PUU-XI/2013, mengenai pengujian Undang Undang No 7 Tahun 2017 tentang Pemilihan Umum terhadap Undang-Undang Dasar Negara Republik Indonesia tahun 1945, dalam Himpunan Peraturan Perundang-Undangan Mengenai Partai Politik dan Pemilihan Umum, (Jakarta, Sekjen dan Badan Keahlian DPR RI: 2018) hal 555
} 
ideologi daripada transaksi politik yang berbasis komposisi dan perolehan kursi di parlemen.

\section{Kerangka Konseptual: Presidensialisme dan Pemerintahan yang Stabil}

Dalam sistem pemerintahan presidensial, basis legitimasi kekuasaan presiden berasal langsung dari rakyat yang memilihnya, bukan dari parlemen, sebagaimana dalam sistem parlementer. Maka sebagai konsekuensi dari kekuasaan langsung dari rakyat, maka presiden hanya dapat diturunkan oleh rakyat melalui mekanisme pemilihan umum yang dilakukan secara periodik. ${ }^{5}$ Dalam relasinya dengan parlemen, presiden tidak bertanggung jawab kepada parlemen, serta tidak dapat membubarkan parlemen. Kedua lembaga ini setara dalam menjalankan fungsi check and balances roda pemerintahan.

Andrew Heywood mengemukakan 3 karakteristik utama dari sistem presidensial. Pertama, Presiden adalah seorang kepala negara, sekaligus juga sebagai kepala pemerintahan. Kedua, Presiden menentukan secara langsung komposisi kabinet, dan menteri-menteri bertanggung jawab secara langsung kepada presiden. Ketiga, menteri-menteri kabinet bukan bagian dari parlemen, dan juga sebaliknya tidak ada anggota parlemen yang merangkap jabatan sebagai menteri. ${ }^{6}$ Terkait dengan penguatan kekuasaan presiden vis a vis parlemen, Scot Mainwaring melihat bahwa sistem Presidensial ditandai dengan terpisahnya pemilihan antara Presiden dan parlemen, sehingga hasil pemilihan legislatif tidak mempengaruhi kekuasaan eksekutif secara langsung. ${ }^{7}$

Meskipun Presiden memiliki kewenangan besar dalam menjalankan kekuasaan eksekutif, namun dalam pratiknya dibeberapa negara yang menganut sistem presidensial, termasuk di Indonesia, presiden masih harus tetap mendapatkan dukungan mayoritas dari parlemen demi efektifitas jalannnya pemerintahan. Maka akan menjadi sebuah keuntungan politik bagi presiden apabila berasal atau didukung oleh partai pemenang pemilu yang memiliki kursi mayoritas di parlemen. Presiden akan mampu mengakselerasikan program-program pemerintahaanya dengan dukungan parlemen. Lebih jauh lagi, Sistem check and balance antara pemerintah dan parlemen akan berlangsung secara konstruktif dan efektif, dimana partai pendukung presiden akan

\footnotetext{
${ }^{5}$ Hanta Yudha., Op.Cit, 2010, hlm 10-11

${ }^{6}$ Andrew Heywood, Politics, Palgrave Foundation, New York,2002, dalam Ibid., hal 14

7 Scot Mainwaring, Presidentialism, Multipartism, and Democracy: The Difficult Combination, Comparative Political Studies: Vol 26, No 2, July 1993. Hal 202-203.
} 
PENGUATAN SISTEM PRESIDENSIAL DI INDONESIA: ANALISIS TERHADAP

UNDANG UNDANG NO. 7 TAHUN 2017 TENTANG PEMILIHAN UMUM

\section{Muhammad Ibrahim Rantau}

memberikan dukungan bagi pemerintah, sedangkan partai oposisi akan mengawasi jalannya pemerintahan.

Sebaliknya Presiden yang didukung atau berasal dari partai minoritas di parlemen akan kesulitan mensinergikan program-program pemerintahannya dengan parlemen. Presiden akan kerapkali menghadapi kontrol yang berlebihan dari parlemen, yang tentunya akan menghambat jalannya pemerintahan. Konflik antara presiden dengan pemilik kursi mayoritas di Parlemen juga akan membuat demokrasi menjadi tidak stabil, mengingat kedua entitas politik ini juga bagian dari representasi rakyat (dual legitimacy). Dalam situasi ini, presiden akan memimpin sebuah pemerintahan minoritas (minority government) yang labil dan mudah dijatuhkan, serta pemerintahan yang terbelah (devided government), karena tidak mendapatkan dukungan yang kuat di parlemen. ${ }^{8}$ Lebih jauh lagi, presidensialisme tidak akan berfungsi dengan baik dalam situasi dimana parlemen memiliki kekuasaan yang besar (legislative heavy), sebagaimana terjadi di Indonesia pasca amandemen UUD 1945 tentang kewenangan DPR.

Dilema presidensialisme juga muncul ketika dipakai dalam sebuah negara yang menganut sistem multipartai. Scot Mainwaring mengungkapkan 3 penyebab dimana sistem multipartai tidak kondusif apabila diterapkan dalam pemerintahan presidensial. Pertama, multipartai dianggap meningkatkan potensi kebuntuan (deadlock) dan kemandegan (immobilism) antara pemerintah dan parlemen, yang tentunya akan mengakibatkan kebuntuan jalannya pemerintahan. Kedua, resiko terjadinya polarisasi ideologis antar partai politik vis a vis pemerintah dalam sistem presidensial dianggap lebih besar dibanding dalam sistem parlementer. Ketiga, Presiden seringkali dituntut untuk membangun koalisi lintas partai guna mendapatkan dukungan dari parlemen bagi jalannya pemerintahan. ${ }^{9}$ Suatu kondisi yang lebih sulit dilakukan dibanding dalam sistem parlementer.

Membangun koalisi lintas partai di parlemen guna mendukung pemerintahan presidensial juga bukan perkara yang mudah. Dibutuhkan kesamaan visi dan platform partai yang permanen bagi koalisi presiden

\footnotetext{
${ }^{8}$ Scot Mainwaring and Matthew Sughart, Juan Linz, Presidentialism, and Democracy: Critical Appraisal, The Hellen Kellog Institute For International Studies, Working PaperJuly 1993. Hal 4-5. Lihat juga dalam Jose Antonio Cheibub, Minority President, Deadlock Situations, and the Survival of Presidential Democracy, dalam Robert A Dahl, Ian Shapiro(ed), The Democracy Source Book, (Cambridge: The MIT Press, 2003) hal 277

${ }_{9}^{9}$ Op.cit., Presidentialism, Multipartism, and Democracy: The Difficult Combination, hal 212-213
}

185 I Pelita - Jurnal Penelitian dan Karya Ilmiah 
agar dapat memberikan dukungan bagi jalannya pemerintahan. Tanpa kesamaan visi dan platform yang permanen, koalisi yang terbentuk akan sangat rentan mengalami perpecahan dan tidak mampu menciptakan disiplin partai bagi dukungan pemerintah di parlemen. Sedangkan kesamaan visi dan platform dalam suasana multipartai sangat sulit untuk bisa tercapai. Maka koalisi kerapkali terbentuk secara pragmatis dan transaksional, sesuai dengan kepentingan politik sesaat dari para elitnya.

Upaya memperkuat sistem presidensial dalam lingkup check and balance dengan parlemen inilah yang menjadi salah satu semangat dilakukannya revisi undang undang pemilu. Produk pemilu, terutama pemilu legislatif diharapkan dapat memberikan ruang bagi upaya penguatan sistem presidensial di Indonesia. Lebih khusus lagi, dilema sistem presidensial yang dibangun diatas pondasi multipartai dapat diatasi dengan salah satu semangat Undang undang no 7 tahun 2017, yaitu untuk lebih memperkuat dukungan presiden di parlemen melalui ambang batas presiden (presidential trashhold) dan penyederhanaan jumlah partai politik di parlemen melalui ambang batas parlemen (parlementary trashold).

\section{Penguatan Demokrasi Presidensial dalam Undang Undang No 7 Tahun 2017 Tentang Pemilu.}

Undang undang No 7 Tahun 2017 tentang Pemilihan Umum disahkan secara resmi melalui sidang paripurna DPR RI pada kamis 20 Juli 2017, sebagai payung hukum bagi penyelenggaraan pemilu presiden dan wakil presiden serentak dengan Pemilu anggota DPR, DPD, dan DPRD Provinsi dan Kabupaten/Kota pada tahun 2019. Semangat untuk memperkuat sistem presidensial tampak dalam beberapa bagian dalam undang undang tersebut, seperti peningkatan ambang batas presiden (presidential trashold) yang mengharuskan partai politik di parlemen untuk membentuk koalisi besar agar dapat mengusung calon presiden. Meskipun disisi lain juga terdapat kontradiksi dengan upaya penguatan sistem presidensial, seperti pilihan untuk menggunakan proporsional terbuka sebagai sistem pemilu. ${ }^{10}$ Namun penelitian ini hanya akan terfokus pada

\footnotetext{
${ }^{10}$ Proporsional terbuka mendorong perilaku pemilih kearah split voters, dimana pemilih akan cenderung memilih calon legislatif dari figur lokal yang berinteraksi langsung dengan masyarakat, dibanding memilih partai politik. Dalam hal ini pilihan pemilih terhadap calon legislatif cenderung tidak terkait dengan pilihan terhadap calon presiden. Dalam kondisi split voters sangat terbuka kemungkinan Presiden yang terpilih bukan berasal dari partai yang mendapatkan kursi mayoritas di parlemen. Berbeda dengan sistem proporsional tertutup dimana pemilih akan terfokus kepada partai politik. Proporsional tertutup akan
} 
PENGUATAN SISTEM PRESIDENSIAL DI INDONESIA: ANALISIS TERHADAP

UNDANG UNDANG NO. 7 TAHUN 2017 TENTANG PEMILIHAN UMUM

semangat penguatan sistem presidensial, daripada kontradiksi yang ada didalamnya.

Paling tidak, terdapat 3 poin dalam Undang Undang tersebut yang terkait dengan upaya penguatan demokrasi presidensial di Indonesia. Pertama, keserentakan pemilu presiden dan pemilu anggota DPR, DPD, dan DPRD. Kedua, ambang batas pemilihan presiden dan wakil presiden (presidential trashold). Ketiga, ambang batas parlemen (parlementary trashold). Ketiga poin tersebut merupakan bagian dari beberapa pasal krusial yang keputusannya harus diselesaikan melalui rapat paripurna DPR RI.

Keserentakan pemilu Presiden dan pemilu anggota DPR merupakan raison d'etre dari lahirnya Undang Undang No 7 tahun 2017 tersebut. Melalui putusan No. 14/PUU-XI/2013, Mahkamah Konstitusi mengamanatkan kepada Pemerintah dan DPR untuk segera melakukan revisi undang undang pemilu demi pelaksanaan pemilihan presiden dan legislatif yang memiliki landasan hukum yang kuat. Dalam amar putusannya, Mahkamah Konstitusi mengabulkan permohonan pemohon bahwa pelaksanaan pemilu legislatif yang mendahului pemilu Presiden ditengarai menyebabkan munculnya beberapa faktor yang menjadi penghambat kemajuan demokrasi dan efektifitas pemerintahan presidensiil di Indonesia. Pertama, Pemilu legislatif yang mendahului pemilihan presiden menyebabkan terjadi politik transaksional yang berlapis lapis, terutama ketika pencalonan Presiden dan Wakil Presiden yang bersandar pada ketentuan Presidential Treshold. ${ }^{11}$ Partai politik yang prosentase suaranya memenuhi ambang batas presiden akan memiliki daya tawar transaksi yang tinggi ketika berhadapan dengan kandidat calon presiden dan wakil presiden, terutama apabila kandidat bukan berasal dari kader internal.

Pemilu legislatif yang biasanya hanya berselang beberapa bulan sebelum pemilihan presiden akan memberikan ruang bagi terjadinya transaksasi transaksi politik antara calon presiden dengan partai

mendorong terjadinya Coatail effect dimana pemilih akan cenderung memilih presiden dan partai politik yang sama. Lihat dalam, Kajian Sistem Kepartaian, Sistem Pemilu, dan Sistem Presidensial, Bagian Analisis Teknis Pengawasan dan Potensi Pelanggaran BAWASLU RI, 2015. Hal 73-74

11 Putusan Mahkamah Konstitusi No.14/PUU-XI/2013, mengenai pengujian Undang Undang No 7 Tahun 2017 tentang Pemilihan Umum terhadap Undang-Undang Dasar Negara Republik Indonesia tahun 1945, dalam Himpunan Peraturan Perundang-Undangan Mengenai Partai Politik dan Pemilihan Umum, (Jakarta, Sekjen dan Badan Keahlian DPR RI: 2018)

187 I Pelita - Jurnal Penelitian dan Karya Ilmiah 
pengusungnya, dan antar partai pengusung yang satu dengan lainnya. Dengan keserentakan pemilu presiden dan pemilu legislatif, maka calon presiden akan memiliki waktu yang relatif panjang, yaitu 5 tahun, untuk dapat menyesuaikan diri dengan visi dan misi partai politik pengusung, sekaligus meminimalisir potensi politik transaksional ${ }^{12}$. Selain itu ambang batas presiden yang diambil dari pemilu legislatif periode sebelumnya, akan memberikan waktu bagi partai politik yang memiliki kuota calon presiden untuk dapat menyiapkan kader terbaiknya guna mengikuti kontestasi pemilihan presiden dan wakil presiden. Presiden terpilih dengan demikian tidak mendapatkan dukungan semu dari partai pengusungnya

Kedua, Mahkamah Konstitusi berpendapat bahwa, pemilihan umum serentak merupakan semangat yang telah muncul dalam perumusan perubahan UUD 1945, sebagaimana dapat dilihat dalam risalah rapat Panitia Ad hoc I Badan Pekerja MPR RI yang mempersiapkan draft perubahan UUD 1945. Dalam draft tersebut telah disepakati bahwa "yang dimaksud pemilu itu adalah pemilu untuk DPR, pemilu untuk DPD, pemilu untuk presiden dan wakil presiden, dan DPRD. Jadi, diletakkan dalam satu rezim pemilu" Selanjutnya dibahas pula tentang teknis pemungutan suara yang akan menggunakan lima kotak suara, yaitu pemilihan Presiden, DPD, DPR RI, DPRD I, dan DPRD II. ${ }^{13}$ Maka Pemilihan Umum Presiden dan Legislatif secara serentak adalah salah satu bagian dari semangat dasar amandemen UUD 1945 itu sendiri.

Ketiga, penyelenggaraan pemilu secara serentak dianggap lebih efisien baik dalam proses penyelenggaraan maupun penghematan anggaran negara. Pemilu presiden dan legislatif yang dilakukan secara terpisah akan membebani anggaran negara secara berlapis lapis, terutama dalam pembiayaan sumber daya manusia penyelenggara pemilu. Selain itu ongkos politik yang dikeluarkan oleh peserta pemilu, terutama partai politik juga akan lebih ringan, terutama dalam publikasi dan pembiayaan jaringan serta relawan. Mesin partai politik akan bergerak mensukseskan dua sasaran sekaligus, yaitu pemenangan partai dan calon presiden yang diusungnya. Pada akhirnya, pemilu serentak juga akan mengurangi suhu

\footnotetext{
${ }^{12}$ Undang Undang No 7 tahun 2017 mensyaratkan presidensial threshold sebesar 20 persen dari total suara nasional atau 25 persen dari jumlah kursi di DPR. Ketentuan tersebut diambil dari hasil pemilihan legislatif periode sebelumnya. Lihat dalam Undang Undang No 7 Tahun 2017 tentang Pemilihan Umum, pasal 222.

${ }^{13}$ Pendapat Mahkamah Konstitusi dalam amar putusan Mahkamah Konstitusi No.14/PUU$\mathrm{XI} / 2013$. Lihat juga dalam Naskah Komprehensif Perubahan Undang Undang Dasar 1945, latar belakang, proses, dan hasil pembahasan 1999-2002, (Jakarta: Setjen DPR RI, 2002) Buku V Pemilihan Umum, hal 602
}

188 I Pelita - Jurnal Penelitian dan Karya Ilmiah 
PENGUATAN SISTEM PRESIDENSIAL DI INDONESIA: ANALISIS TERHADAP

UNDANG UNDANG NO. 7 TAHUN 2017 TENTANG PEMILIHAN UMUM

dan ketegangan politik di tengah masyarakat, sehingga pasca pemilu, pemerintah dapat berkonsetrasi penuh untuk melaksanakan pembangunan.

Poin kedua dalam Undang Undang No 7 tahun 2017 yang merupakan bagian dari upaya memperkuat sistem presidensial adalah penentuan ambang batas pengusung presiden. Dalam pasal 222 undangundang pemilu tentang ambang batas presiden ditetapkan bahwa syarat untuk dapat mengajukan calon presiden paling tidak harus memperoleh $20 \%$ suara sah secara nasional, atau memiliki 25\% jumlah kursi di DPR RI dalam pemilihan legislatif. Untuk pemilihan Presiden 2019, maka syarat ambang batas presiden ditentukan dari hasil pemilihan legislatif periode sebelumnya, yaitu Pemilihan legislatif 2014. ${ }^{14}$

Ketentuan ambang batas presiden dalam pasal ini mengundang polemik dan perdebatan panas baik dikalangan akademisi, maupun ditengah masyarakat. Pihak yang menolak pasal ini beranggapan bahwa ambang batas presiden yang tinggi justru memperlemah sistem presidensial, karena partai politik yang tidak memenuhi syarat yang ditetapkan, dipaksa untuk melakukan transaksi-transaksi politik untuk membentuk koalisi besar guna memenuhi ambang batas pencalonan presiden. ${ }^{15}$ Dengan demikian, presiden yang terpilih dari koalisi besar ini kerap tersandera oleh komitmen transaksional yang tentunya berpotensi mengganggu efektifitas jalannya pemerintahan.

Namun disisi lain, ambang batas presiden yang tinggi justru dapat memberikan dukungan yang kuat bagi presiden di parlemen. Sistem presidensial yang tidak murni di Indonesia mensyaratkan seorang presiden terpilih untuk mendapatkan dukungan kuat di DPR demi efektifitas jalannya pemerintahan. Dalam proses pembuatan undang undang, baik atas inisiatif DPR maupun Pemerintah, sistem ketatanegaraan kita juga mensyaratkan saling dukung antara Presiden dan parlemen dalam suatu

\footnotetext{
${ }^{14}$ Undang Undang Republik Indonesia Nomor 7 tahun 2017 Tentang Pemilihan Umum, Pasal 222 Tentang Tata cara Penentuan, Pengusulan, dan Penetapan Pasangan Calon, dalam Himpunan Peraturan Perundang Undangan Mengenai Partai Politik dan Pemilihan Umum, (Jakarta, Sekjen dan Badan Keahlian DPR RI: 2018) hal 145

${ }^{15}$ Pihak-pihak yang menolak ketentuan ambang batas presiden ini mengajukan uji materi ke Mahkamah Konstitusi, karena pasal ini juga dianggap melanggar hak-hak konstitusional warga negara untuk mencalonkan diri sebagai Presiden dan wakil presiden. Permohonan uji materi diajukan oleh Hadar Nafis Gumay, Busyra Muqodas, Chatib Basri, Faisal Basri, Titi Anggraini, dll. Permohonan uji materi tentang pasal 222 Undang Undang Pemilu ini kemudian ditolak secara keseluruhan oleh Mahkamah Konstutisi dalam putusan Mahkamah No 49/PUU-XVI/2018.
}

189 I Pelita - Jurnal Penelitian dan Karya Ilmiah 
koalisi besar. Maka, ambang batas pencalonan presiden yang tinggi akan memberikan modal politik di parlemen bagi presiden terpilih, untuk memperkuat pemerintahan.

Tanpa mendapatkan dukungan kuat di parlemen, Presiden akan menjalankan suatu pemerintahan yang terbelah (devided government), sebagaimana yang dialami oleh presiden Susilo Bambang Yudhoyono (SBY) dan Presiden Joko Widodo (Jokowi) di fase awal pemerintahan mereka. Presiden SBY yang terpilih bukan dari partai pemenang pemilu harus berusaha keras meraih dukungan di DPR, sebelumnya akhirnya Wakil Presiden Jusuf Kalla berhasil mengambil alih kepemimpinan di partai Golkar, sehingga dapat mengamankan dukungan mayoritas bagi pemerintah di DPR. Sedangkan Presiden Jokowi, meskipun diusung oleh PDIP sebagai partai pemenang pemilu, namun harus menghadapi manuver politik dari Koalisi Merah Putih (KMP) pendukung Prabowo Subianto, yang lebih menguasai suara mayoritas di DPR. Maka tidak mengherankan apabila di fase awal pemerintahannya Presiden Jokowi lebih disibukkan dengan urusan "transaksi politik" guna memecah Koalisi Merah Putih demi merebut dukungan di parlemen.

Akhirnya, baik ambang batas pencalonan presiden yang rendah maupun tinggi, keduanya sama-sama memiliki potensi menciptakan politik transaksional yang akan mengganggu jalannya pemerintahan presidensial yang efektif. Ambang batas yang tinggi akan memaksa calon presiden, yang tidak memiliki prasyarat dukungan suara dan kursi, untuk melakukan transaksi demi membentuk koalisi besar pencalonan. Sedangkan ambang batas rendah juga berpotensi melahirkan seorang presiden terpilih yang berasal dari partai kecil dengan dukungan yang minim di parlemen, Maka Presiden terpilih akan disibukkan dengan upaya mengamankan dukungan politik di parlemen, yang tentunya juga akan menganggu efektifitas pemerintahan presidensial.

Maka pilihan untuk menggunakan ambang batas pencalonan yang tinggi, sebagaimana yang ditetapkan dalam Undang Undang No 7 tahun 2017 tentang Pemilu, harus diimbangi dengan upaya penyederhanaan jumlah partai politik di parlemen. Mengingat koalisi yang permanen diantara partai politik dan penyederhanaan jumlah partai politik dianggap dapat mengurangi potensi politik transaksional. Demi kepentingan penyederhanaan jumlah partai politik inilah Undang Undang Pemilu 
PENGUATAN SISTEM PRESIDENSIAL DI INDONESIA: ANALISIS TERHADAP

UNDANG UNDANG NO. 7 TAHUN 2017 TENTANG PEMILIHAN UMUM

menaikan ambang batas parlemen yang sebelumnya sebesar 3,5 persen dari perolehan suara secara nasional, menjadi 4 persen. ${ }^{16}$

Sejarah pemilu di Indonesia pasca reformasi selalu menghasilkan kondisi multi partai ekstrem di parlemen. ${ }^{17}$ Pada pemilu 1999, terdapat 48 peserta pemilu yang menghasilkan 19 partai di DPR. Pada pemilu 2004 terdapat 24 partai peserta pemilu yang menghasilkan 16 partai. Pada pemilu 2009, partai peserta pemilu meningkat sebanyak 38 partai, dengan 9 partai yang berhasil menduduki kursi DPR. Sedangkan pemilu 2014 diikuti oleh 15 partai politik dengan 13 partai yang berhasil memenuhi ambang batas parlemen.

Multi partai ekstrem di DPR dibarengi dengan kondisi bahwa tak satupun diantara partai-partai tersebut yang memiliki jumlah kursi mayoritas. PDIP sebagai partai pemenang pemilu 1999 hanya memiliki 153/ 18\% kursi di DPR. Begitu juga dengan Golkar sebagai partai pemilik kursi terbanyak pada pemilu 2004, hanya memiliki 127 kursi. Sedangkan Partai Demokrat yang memenangkan pemilu 2009 hanya memiliki 148 kursi. Kondisi multi partai ekstrem dengan tanpa partai mayoritas juga terjadi pada pemilu 2014, dimana PDIP sebagai partai pemenang pemilu hanya memiliki 109 kursi di DPR atau 18, 95 \% jumlah suara nasional. ${ }^{18}$

Kondisi multi partai ekstrem dengan tanpa partai mayoritas mengharuskan presiden untuk membentuk sebuah koalisi besar dalam rangka mengamankan dukungan bagi pemerintah di parlemen. Dalam kondisi inilah Presiden kerapkali dipaksa untuk melakukan politik transaksional dengan membagi jabatan politik di Pemerintahan. Apalagi jika presiden yang terpilih berasal dari partai minoritas, dengan koalisi minoritas di parlemen. Suatu kondisi yang tentunya akan memperlemah sistem presidensial dan mengganggu efektifitas jalannya pemerintahan.

\footnotetext{
${ }^{16}$ Undang Undang No 7 Tahun 2017 tentang Pemilihan Umum, pasal 414 ayat 1 Tentang Penetapan Hasil Pemilu, dalam Himpunan Peraturan Perundang Undangan Mengenai Partai Politik dan Pemilihan Umum, (Jakarta, Sekjen dan Badan Keahlian DPR RI: 2018) hal 244

${ }^{17}$ Giovanni Sartori membagi empat sistem kepartaian yang meliputi: 1. Sistem partai tunggal, dimana hanya terdapat satu partai besar. 2. Sistem partai dua partai, dimana terdapat 2 partai relevan. 3. sistem pluralism moderat, dimana terdapat 3-5 partai relevan. 4, sistem multipartai ekstrem, dimana terdapat lebih dari 5 partai besar. Lihat Kuskridho Ambardi, Kompetisi atau Kartelisasi? Framework Teoritik Sistem Kepartaian Di Indonesia, dalam Ichlasul Amal (ed), Teori-teori Mutakhir Partai Politik, (Yogyakarta: Tiara Wacana, 1996) hal 194-196

${ }^{18}$ Lihat dalam, Op.cit., Kajian Sistem Kepartaian, Sistem Pemilu, dan Sistem Presidensial, Kajian Bawaslu RI, hal 70-71
}

191 I Pelita - Jurnal Penelitian dan Karya Ilmiah 
Oleh karena itu pilihan untuk menaikan ambang batas parlemen menjadi 4 persen akan berefek kepada penyederhanaan jumlah partai politik di DPR. Beberapa naskah yang dijadikan studi akademik dalam Undang Undang Pemilu menyebutkan bahwa jumlah partai politik yang ideal di Indonesia, dengan tetap mempertimbangkan asas representasi masyarakat Indonesia yang sangat beragam adalah 3-5 partai politik relevan. Dengan 3-5 partai akan terbentuk polarisasi kekuatan politik di parlemen antara partai pendukung pemerintah dan partai oposisi. Jumlah partai politik yang sederhana juga akan memudahkan presiden mendapatkan koalisi untuk mendukung jalannya pemerintahan presidensial yang efektif dan efisien.

\section{B. PENUTUP}

Naiknya ambang batas pencalonan presiden dan ambang batas parlemen dalam Undang Undang No 7 tahun 2017 tentang Pemilu, mengindikasikan adanya keinginan untuk memperkuat sistem presidensialisme di Indonesia. Kenaikan ambang batas presiden menjadi 20 persen jumlah suara nasional atau 25 persen jumlah kursi di parlemen, diharapkan dapat memberikan modal bagi presiden terpilih untuk mendapatkan dukungan kuat di parlemen. Demikian juga dengan kenaikan ambang batas parlemen menjadi 4 persen diharapkan dapat menyederhanakan jumlah partai politik, sehingga sistem kepartaian yang sederhana dapat kompatibel dengan sistem presidensial di Indonesia. Disamping itu keserentakan pemilu legislatif dan pemilihan presiden serta wakil presiden juga diharapkan dapat memberikan efek bagi terbentuknya koalisi yang permanen baik di parlemen maupun pemerintahan, serta mengurangi potensi politik transaksional.

Namun begitu, upaya penguatan sistem presidensial melalui revisi undang undang pemilu dapat juga menjadi ambivalen dan justru memperlemah posisi Presiden dihadapan parlemen. Ambang batas pencalonan Presiden yang tinggi selain dapat menjadi modal juga dapat menjadi ancaman ketika calon presiden, terutama dari partai dengan perolehan suara kecil, dituntut untuk melakukan politik transaksional demi memenuhi ambang batas pencalonan. Ambang batas rendah cenderung menguntungkan kandidat calon presiden sebelum pemilihan presiden dimulai. Sedangkan ambang batas presiden yang tinggi akan cenderung memberikan keuntungan bagi presiden terpilih untuk dapat mengkonsolidasikan parlemen demi jalannya pemerintahan presidensial yang efektif dan efisien. 
PENGUATAN SISTEM PRESIDENSIAL DI INDONESIA: ANALISIS TERHADAP UNDANG UNDANG NO. 7 TAHUN 2017 TENTANG PEMILIHAN UMUM

Muhammad Ibrahim Rantau

\section{Referensi}

Amal, I. (1996). (ed), Teori-teori Mutakhir Partai Politik, Yogyakarta: Tiara Wacana.

Dahl, R. A., \& Shapiro, I. (2003). The Democracy Source Book, Cambridge: The MIT Press.

Heywood, A. (2002). Politics. New York: Palgrave Foundation.

Mainwaring, S. (1993). Presidentialism, Multipartism, and Democracy: The Difficult Combination. Comparative Political Studies: Vol 26, No 2, July 1993.

Yudha, H. (1998). Presidensialisme Setengah hati: Dari Dilema ke Kompromi, Jakarta: Gramedia Pustaka Utama. 